\title{
An Enzyme-Free Glucose Electrochemical Sensor for Detection of the Glucose in Serum Based on Nickel Nanoparticle/Carbon Quantum Dots
}

\author{
Xiaoling Yang ${ }^{1,2}$, Zhihong Yan ${ }^{1}$, Ruihui Huang ${ }^{2}$, Jing Wang ${ }^{2}$, Yingde Cui ${ }^{3, *}$, Yi Liu ${ }^{1,2, *}$ \\ ${ }^{1}$ College of Pharmacy, Guangdong Pharmaceutical University, Guangdong, China. \\ ${ }^{2}$ School of pharmaceutical and chemical engineering, Guangdong Pharmaceutical University, \\ Guangdong, China \\ ${ }^{3}$ Guangzhou Vocational College of Science and Technology, Guangzhou, Guangdong 510550, China. \\ *E-mail:13602880087@139.com,1499088964@qq.com
}

doi: $10.20964 / 2021.05 .57$

Received: 9 January 2021 / Accepted: 24 February 2021 / Published: 31 March 2021

\begin{abstract}
A sensitive enzyme-free glucose electrochemical sensor was developed by continuous cyclic voltammetry. In this system, the carbon quantum dots are a kind of green environmental protection materials and the nickel nanoparticle is excellent electrocatalysts. The proposed sensor based on the above two kinds of materials was successfully applied to determine glucose in serum. The developed sensor exhibition wider response range $(0.005 \sim 8.0 \mathrm{mM})$ and possessed lower detection limit $(0.98 \mu \mathrm{M})$. Moreover, as-prepared biosensor exhibited prominent selectivity, stability and reproducibility and it was used for the determination of glucose in serum with satisfactory results.
\end{abstract}

Glucose sensor; Nickel nanoparticles; Carbon quantum dots; Enzyme-free

\section{$\underline{\text { FULL TEXT }}$}

(C) 2021 The Authors. Published by ESG (www.electrochemsci.org). This article is an open access article distributed under the terms and conditions of the Creative Commons Attribution license (http://creativecommons.org/licenses/by/4.0/). 